\title{
Disseminating and Organizing
}

\section{Dissémination et organisation}

\author{
by LESLIE L. ROOS, PHD \\ Manitoba Centre for Health Policy \\ Faculty of Medicine, University of Manitoba, \\ Winnipeg, $M B$
}

\begin{abstract}
How do we reach a wide variety of possible readers? This commentary notes various ways in which academic information has been organized on the Web, stressing the usefulness of different formats and approaches. The Social Science Research Network provides a way for publications to become widely known at an early stage. Such Webbased facilities for one-stop searching are needed for academics and policy makers interested in health services, health policy, public health and population health.
\end{abstract}

\section{Résumé}

Comment atteindre le plus grand nombre de lecteurs potentiels? Ce commentaire relève les diverses méthodes d'organisation de l'information scientifique sur Internet, en mettant l'accent sur l'utilité des approches et des formats différents. Le Social Science Research Network offre un service de diffusion précoce des publications. De tels outils intégrés de recherche en ligne sont nécessaires autant pour les chercheurs que les décideurs qui sintéressent aux services de santé, aux politiques en matière de santé, à la santé publique et à la santé de la population. 
I N the i93os, a Russian émigré at Stanford University having Difficulties in getting participants for his conference complained to my uncle: "You know, Harold, we live in a small, remote province." To Canadians, such complaints may still have some resonance, but Internet access provides an audience for our work, if we just take appropriate advantage of it.

Of particular importance is the phenomenon of the long tail, the "multitude of users with narrow interests and needs that, in aggregate, are in the majority" (Schwartz 2006: 39). Given the low costs of storage and the worldwide reach of the Internet, Canadian researchers would find it worthwhile to post their findings on the Web. The Web permits going beyond Canada to address the dramatically larger worldwide audience at minimal cost. Those of us in small, remote provinces will find an audience if we get our work up and attract notice by other websites; the new economics of knowledge dissemination facilitates finding readers. The more links, sites and formats, the better.

My previous commentaries have noted how networks can be created and enhanced using the Internet. Several different types of communication and dissemination strategies aid in organizing the fire hose of available information:

1) those that are basically informative, presenting what an organization is doing and has done. Papers and reports may be listed or included on the site.

2) those oriented towards working knowledge (such as the research protocol/glossary/concept dictionary within the Manitoba Centre for Health Policy website). Information initially organized to facilitate the work of a particular centre can be further refined to help a wider audience.

3) the simple structure for lectures in PowerPoint used by the Epidemiology Supercourse. PowerPoint slides have an advantage in being both easy to submit and easy to download in parts of the world with only narrow bandwidth capability.

4) the fancier sets of slides and notes organized around term-length courses (characteristic of the OpenCourseWare philosophy pioneered at MIT and adapted by the Johns Hopkins School of Public Health).

5) those that help students and researchers find published material. Some are free to the user; GoogleScholar (funded by advertising) and PubMed (a service of the National Library of Medicine and the National Institutes of Health in the United States) are among the most popular. Others are funded by subscription (the services provided by the Institute for Scientific Information are generally available through academic libraries).

How do we reach broader audiences? Beyond traditional journals, a variety of publication formats (including Web-based journals) are available. The Epidemiology Supercourse reaches an audience difficult to address by other strategies. Besides helping those who may lack journals and OECD-type incomes, this is a good way to 
spread the word! OpenCourseWare can be easily simplified for the Supercourse; those with lots of bandwidth who pick up information there may well wish to link to the more elaborate sites.

How do we locate timely information? The "grey literature" is obviously missing from my simple listing above. Although often present in the websites of particular organizations, it is likely to be hard to find. Literature review projects characteristically list many places to look besides those noted above, but more centralized organization would be helpful. The Social Science Research Network (SSRN) provides a useful example. As described in Wikipedia (a good place to look for terms, even statistical ones), "in economics, and to some degree in law (especially in the field of law and economics), almost all papers will now be published in SSRN before being submitted to an academic journal." The SSRN eLibrary is made up of both an Abstract Database (with abstracts on almost 124,000 working and forthcoming papers) and an Electronic Paper Collection (about 95,000 downloadable documents). Currently, SSRN is built around 10 networks, each with a director. Business schools are increasingly represented, with networks for research in accounting, entrepreneurship, information systems, measurement and marketing. This facilitates publications becoming "widely known in the academic community at an early stage."

To the best of my knowledge, there is nothing like this in the fields of health services research, healthcare policy, public health, or population health. Students and researchers (Canadian or otherwise) must now search across conference proceedings and research centre websites to find material. Thirteen Canadian academic health policy research centres have been identified by Mekel and Shortt (2005). A variety of university departments and schools archive papers on community and population health. Some government departments may participate. A facility for "one-stop searching" to find timely materials is desperately needed.

Who will pay for what? The principals of the Social Science Research Network have tried to make copies of papers free or at low cost to users, although some have expressed concern about whether this policy will continue. SSRN's eLibrary also includes papers from "fee-based partner publications."

Differences between the paid and free philosophies are highlighted in a chapter ("The Ultimate Pin Factory") in a new book, Knowledge and the Wealth of Nations (Warsh 2006). Of particular relevance is the material on Aplia, founded by the wellknown economist Paul Romer. Aplia is designed to sell (and grade!) Web-accessible exercises to the large university market for teachers of elementary and intermediate economics. What good teaching exercises (preferably Web-based) are available for small markets, for readers of Healthcare Policy? Are we getting no synergies from the Regional Training Centres? Leadership by research centres and funding agencies is called for. 
Correspondence may be directed to: Leslie L. Roos, Manitoba Centre for Health Policy, Department of Community Health Sciences, Faculty of Medicine, University of Manitoba, Rm. 408 - 727 McDermot Avenue, Winnipeg, MB R3E 3P5; tel: 204-789-3773; fax: 204-789-3910; email: Leslie_Roos@cpe.umanitoba.ca.

\section{REFERENCES}

JHSPH OpenCourseWare. 2006. Retrieved July 13, 2006. <http://ocw.jhsph.edu> . Manitoba Centre for Health Policy. 2006 (February 23). Research Resources. Retrieved July 13, 2006. <http://www.umanitoba.ca/centres/mchp/concept $>$.

Manitoba Centre for Health Policy. 2006 (June 2). Supercourse. Retrieved July 13, 2006. < http:// www.pitt.edu/ super1/index.htm>.

Mekel, M. and S.E.D. Shortt. 2005. "Coming of Age and Taking Stock: The State of Academic Health Policy Research Centres in Canada." Healthcare Policy 1(1): 140-50.

Schwartz, J. 2006. "On the Grid: Grid Computing Is Becoming an Affordable Utility for Everyone." Technical Review 109(2): 38-39.

Social Science Research Network. 2006. Retrieved July 13, 2006. <http://www.ssrn.com>. Warsh, D. 2006. Knowledge and the Wealth of Nations. New York: W.W. Norton.

Wikipedia. 2006 (June 29). Retrieved July 13, 2006. <http://en.wikipedia.org/wiki/Wikipedia>.

\section{Call to Authors}

The Web has emerged as a common vehicle for knowledge transfer and dissemination. Yet, it's a tool that is relatively new and often in a state of change as new technologies become available. The editors are interested in your organization's experience with Web-based knowledge transfer - what works and what doesn't? And how do you know?

Send your submissions to: Rebecca Hart, Managing Editor, at rhart@longwoods.com.

\section{Appel aux auteurs}

Dès son apparition, le web sest imposé comme un instrument à la fois de transfert et de diffusion des connaissances, mais il n'en demeure pas moins un outil relativement nouveau, qui ne cesse d'évoluer au fur et à mesure que de nouvelles technologies voient le jour. Les rédacteurs veulent savoir comment votre organisme vit le transfert des connaissances par le web : ce qui fonctionne, ce qui ne fonctionne pas et comment vous vous en rendez compte?

Veuillez faire parvenir vos réponses à Rebecca Hart, rédactrice en chef à l'adresse : rhart@longwoods.com. 